2. To: (Recelving Oroanization)

Utility Technical Support, 71620

5. Proj./Prog./Dept. $/$ iv.:

System

8. Originutor Remarks:

ETN-94-0165

Attached are the design calculation for the strong-back

safety 7 atch.

Please distribute copies per block $\$ 17$

11. Receiver Remarks:
Waste Tank remediation
3. From: (Orisinatino Oranization)

Utility Technical Support 71620

6. Cog. Engr.:

GN DeSantis
6. Related EDT Mo.:

$\mathbf{N} / \mathbf{A}$

7. Purchase Ordar Mo.:

N/A

9. Equip./Component Mo.:

N/A

10. System/de./Fecillity:

N/A

12. Major Aesm. Dug. Mo.:

N/A

13. Pernit/Pernit Application Vo.: N/A

14. Required Response Date:

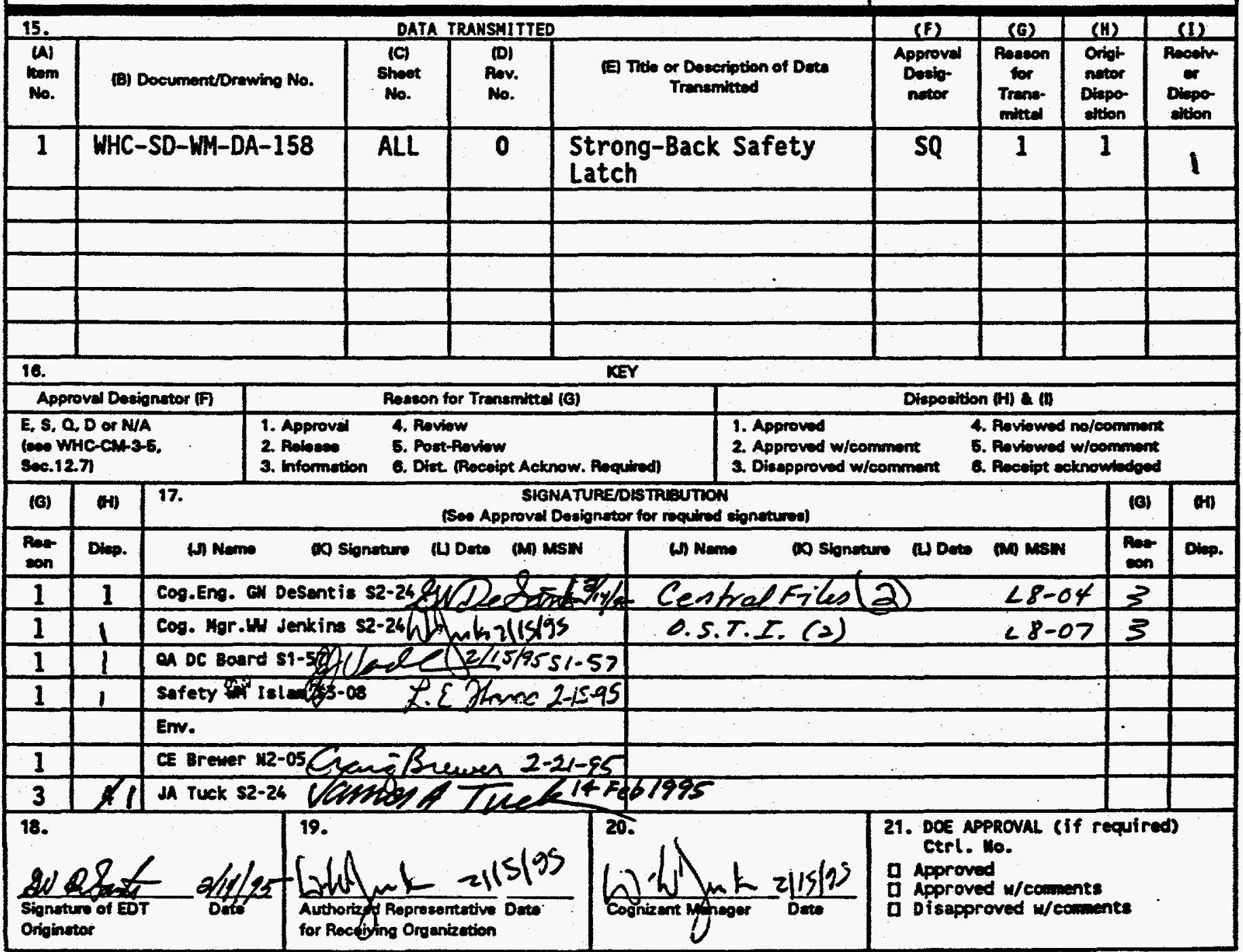




\section{DISCLAIMER}

Portions of this document may be illegible in electronic image products. Images are produced from the best available original document. 


\section{RELEASE AUTHORIZATION}

Document Number: WHC-SD-WM-DA-158, REV 0

Document Title: STRONG-BACK SAFETY LATCH

Release Date: $\quad 3 / 6 / 95$

This document was reviewed following the procedures described in WHC-CM-3-4 and is:

APPROVED FOR PUBLIC RELEASE

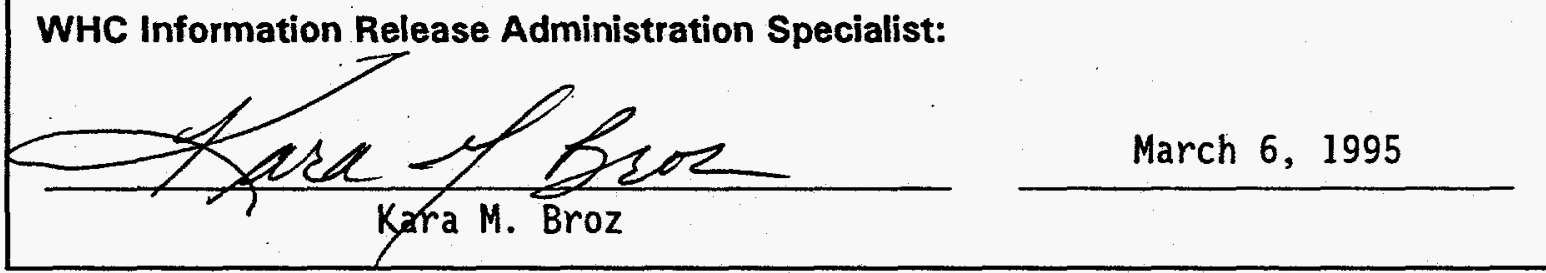

TRADEMARK DISCLAIMER. Reference herein to any specific commercial product, process, or service by trade name, trademark, manufacturer, or otherwise, does not necessarily constitute or imply its endorsement, recomendation, or favoring by the United States Government or any agency thereof or its contractors or subcontractors.

This report has been reproduced from the best available copy. Available in paper copy and microfiche. Printed in the United States of America. Available to the U.S. Department of Energy and its contractors from:

U.S. Department of Energy

Office of Scientific and Technical Information (OSTI)

P.0. Box 62

Oak Ridge, TN 37831

Telephone: (615) 576-8401

Available to the public from:

U.S. Department of Commerce

National Technical Information Service (NTIS)

5285 Port Royal Road

Springfield, VA 22161

Telephone: (703) 487-4650 


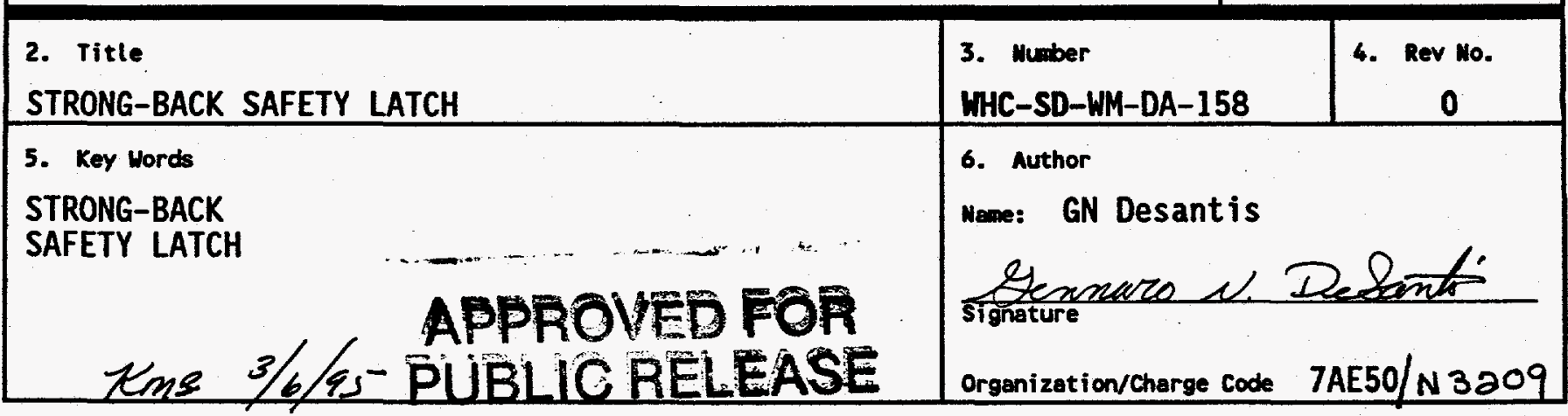

\section{Abstract}

This Design Alaysis provides stress calculation for selecting the required materials needed for the Strong-Back Safety Latch.

8. PuRpose AND USE OF DOCUMENT - This document was prepared for use With in the U.S. Department of Energy and its contractors. It is to be used only to perform, direct, or integrate nork under U.S. Department of Energy contracts. This document if not approved. for public release until reviewed.

PATENT STATUS - This docunent copy, since it is transmitted in advance of patunt clearance, is made availabl in confidence solely for use in performance of work unde contracts with the U.S. Department of Energy. This document/s not to be published nor its contents otherwise disseminated or sed for purposes other than specified above before ratent approys for such release or use has been secured, upon reques from th Patent Counsel, U.S. Department of Energy Field office, Richland LAA.

DISCLAIMER - This report as prepared as on account of work sponsored by an agency of the United States Government. Nei ther the United States Government nor any agaocy thereof, nor any of their employees, nor any of their contractoss, subcontractors or their employees, makes any warranty, express or implied, or assumes any legal liability or tesponsibility for the ackuracy, completeness, or any third party' use or the results of such bae of eny information, apparatus, procuct, or process disclosed, or repinesents that its use would not ipiringe privately owned rights. Reference herein to any specific comercial product, process, or service try trade name, tradema $x$, manufacturer, or otherwise, does not necessarily constyute or imply its endorsement, recommendation, or Fvoring by the United states Government or any agency thereof her its antractors or subcontractors. The views and opinions of athors expressed herein do not necessarily state or reflect those of the United States Government or any agency thereof.

10. RELEASE STNMP

OFFICIAL RELEASE
BYWHC
DATE MAR 061995
dta. 4




\title{
STRONG-BACK SAFETY LATCH ANALYSIS
}

\author{
October 1994
}

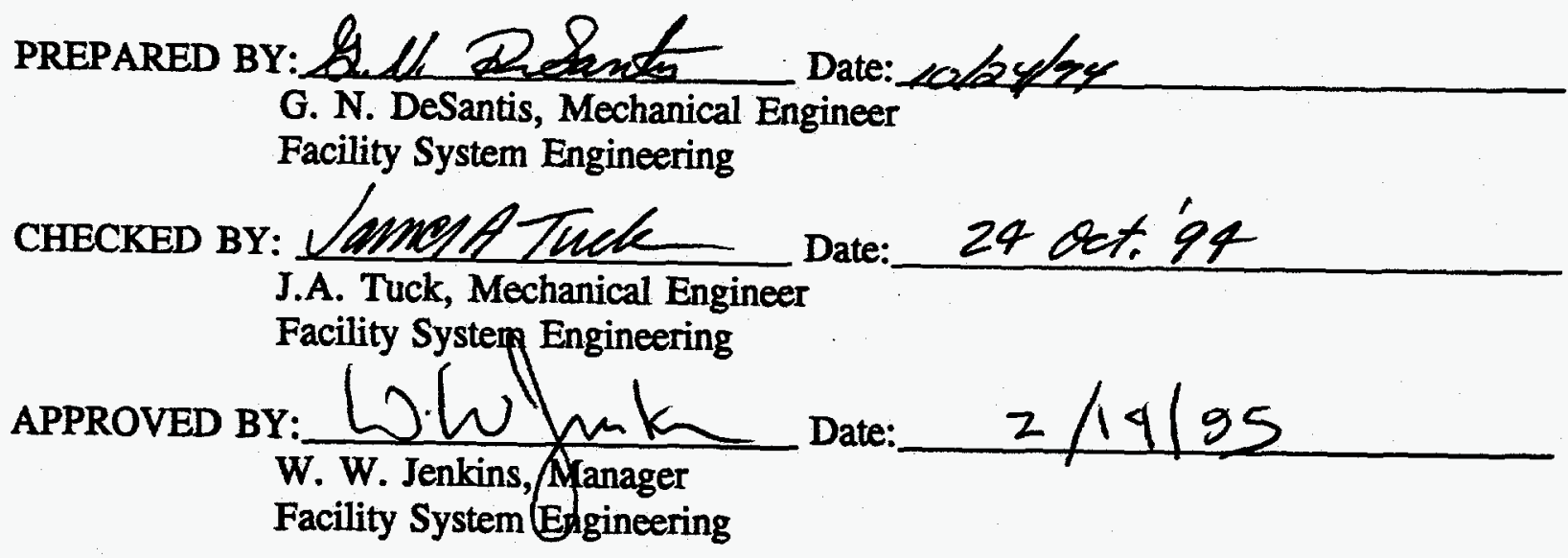

\section{DISCLAIMER}

This report was prepared as an account of work sponsored by an agency of the United States Government. Neither the United States Government nor any agency thereof, nor any of their employees, makes any warranty, express or implied, or assumes any legal liability or responsibility for the accuracy, completeness, or usefulness of any information, apparatus, product, or process disclosed, or represents that its use would not infringe privately owned rights. Reference herein to any specific commercial product, process, or service by trade name, trademark, manufacturer, or otherwise does not necessarily constitute or imply its endorsement, recommendation, or favoring by the United States Government or any agency thereof. The views and opinions of authors expressed herein do not necessarily state or reflect those of the United States Goverument or any agency thereof. 
WHC-SD-WM-DA-158

Revision 0

Page 1 of $242 a$

TABLE OF CONTENT

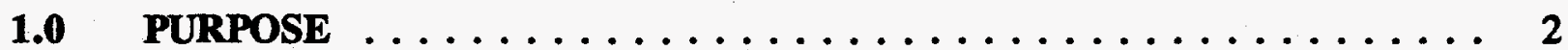

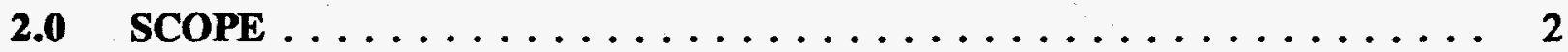

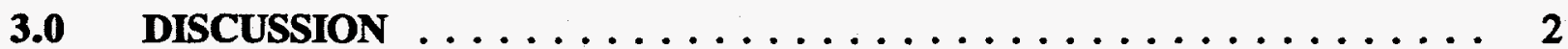

4.0 RESULTS $\ldots \ldots \ldots \ldots \ldots \ldots \ldots \ldots \ldots \ldots \ldots \ldots \ldots \ldots$

5.0 CONCLUSION $\ldots \ldots \ldots \ldots \ldots \ldots \ldots \ldots \ldots \ldots \ldots \ldots \ldots$

6.0 REFERENCES $\ldots \ldots \ldots \ldots \ldots \ldots \ldots \ldots \ldots \ldots \ldots \ldots \ldots$

$6.1 \quad$ Drawings ..................... 4

$6.2 \quad$ Literature $\ldots \ldots \ldots \ldots \ldots \ldots \ldots \ldots \ldots \ldots \ldots \ldots$

7.0 DESIGN CALCULATION $\ldots \ldots \ldots \ldots \ldots \ldots \ldots \ldots \ldots \ldots \ldots$

7.1 List of Symbols $\ldots \ldots \ldots \ldots \ldots \ldots \ldots \ldots \ldots \ldots \ldots$

$7.2 \quad$ Static Analysis $\ldots \ldots \ldots \ldots \ldots \ldots \ldots \ldots \ldots$

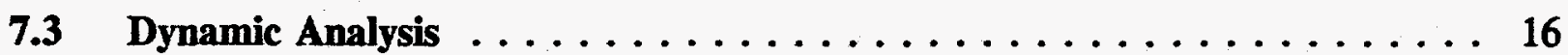

APPENDIX A

TABULATED STRESS $\ldots \ldots \ldots \ldots \ldots \ldots \ldots \ldots \ldots \ldots \ldots \ldots \ldots$

APPENDIX B

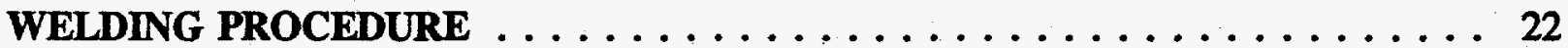




\subsection{PURPOSE}

To resolve the following safety issues and concerns with the strong-back.

1. Inadequate clamping between the strong-back and pump.

2. Strong-Back support legs has no locking device.

3. The crane might pull the stud-bolts out of the concrete in shop.

4. The crane might lift the flatbed trailer.

\subsection{SCOPE}

To resolve the above safety items by designing a safety latch, pivot brace and a rear leg stabilizer lock.

\subsection{DISCUSSION}

The following calculation decides the integrity of the safety latch that will hold the strongback to the pump during lifting. The safety latch will be welded to the strong-back, and

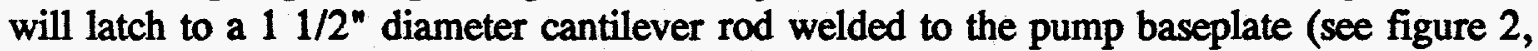
section 7.0).

The calculations assure the materials selected are of the appropriate strength to withstand the weight of the strong-back $(1,634 \mathrm{lbs})$ during lifting. The weight of the pump will be carried by the crane at the lifting bails, which will be attached to the pump. A safety factor of (3) has been used as part of the design criteria, per the Hanford Site hoisting and Rigging Manual (DOE-RL 1993).

The safety latch has been designed so that an operator may release the jaws by pulling on a wire cable leading up to the latch, freeing the pump (see figure 2, section 7.0).

The pivot brace is designed to be mounted onto the flatbed trailer, and the floor of the shop. The Brace will allow the strong-back to pivot during lifting, and to move vertical, eliminating the issue of lifting the trailer or pulling the bolt out of the concrete floor (see section 6.0 for reference drawing).

The rear leg stabilizer lock will constrain the strong-back rear support by eliminating any forward, or lateral movements, allowing the operator to place the safety plate over the legs, and be bolted (see section 6.0 for reference drawing). 
The current design of the strong-back holds the pump in place by two pins on the yoke and two friction clamps at the bottom of the shaft. The safety latch is designed to take the load $(1,634 \mathrm{lbs})$ of the strong-back in the upright position if slippage or failure of the pins occurs. Therefore, all load points are based on a load of $1,634 \mathrm{lbs}$, being placed on the safety latch in the vertical position.

The safety latch will be welded to a piece of structural tubing which will be welded to the strong-back.

Each pump baseplate will be modified with a 1-1/2" diameter cantilever rod, approximately 8 inches long. The cantilever rod will be welded to the pump base. This will be the second link to the safety latch.

\subsection{RESULTS}

The static analysis (see section 7.2) was based on a using a safety factor of 3 , it was found all materials selected for the safety latch components will support the strong-back.

By comparing all the calculated stresses to the tabulated yield points for each of the components and their welds (see Appendix A), the component first to yield would be the shoulder bolt, if a continuously increasing load were applied. The shoulder bolt is fabricated from ASTM A325, which yields at $92 \mathrm{ksi}$. The calculated stress for the shoulder bolt is approximately $25 \mathrm{ksi}$. This stress is based on the shoulder bolt taking the full static load.

The dynamic analysis (see section 7.3) is a conservative approach based on the strong-back free falling $1 / 4$ inch and causing the safety latch to come in contact with the cantilever rod, thereby shock loading the safety latch components. As stated above the first component to yield is the shoulder bolt. Assuming the stress-strain curve for the shoulder bolt is elastic and perfectly plastic, and assuming that all the kinetic energy is absorbed by the shoulder bolt, the analysis shows that the shoulder bolt can absorb 6.7 in-lb in the elastic range, and 6,261 in-lb in the plastic range using an ultimate strain of $0.11 \mathrm{in} / \mathrm{in}$. The kinetic energy that needs to be absorbed is only $414 \mathrm{in}-\mathrm{lb}$ and is far less then the ultimate energy which can be absorbed by the shoulder bolt. Therefore: based on this conservative approach, if all of the kinetic energy is applied to the shoulder bolt, fracture would not occur. It should be noted that the kinetic energy is actually absorbed by all the safety latch components and not just the shoulder bolt. Since the shoulder bolt is the first component to yield (weakest component), once yielding is initiated, and assuming an elastic perfectly plastic stress strain curve for the bolt, no additional load (or stress) will be applied to the remaining components. The shoulder bolt will continue to deform into the plastic range until all the kinetic energy is dissipated by deformation of the shoulder bolt. This analysis shows that the shoulder bolt will not fracture (reach the ultimate strain) if the strong-back falls $1 / 4$ inch. 


\subsection{CONCLUSION}

The purpose of the analysis is to resolve the safety issues dealing with the strong-back listed above in section 1.0 , by analyzing the static and dynamic loading to the safety latch during lifting. The static and dynamic analysis shows that the safety latch will have the integrity to hold the strong-back to the pump if the friction clamps were to fail and the pump was to become free from the strong-back. This analysis proves the safety latch will function as designed, and will meet the requirements of the Lifting and Rigging Manual for under the hook lifting for static loading. This analysis also shows the safety latch is also capable of sustaining shock loading induced by the strong-back falling $1 / 4$ inch.

\subsection{REFERENCES}

6.1 Drawings

Safety Latch

Support \& Stabilizer

Latch Installation

Strong-Back

Pump Run-in
H-2-85424 Rev. 0 sht's 1 thru 3

H-2-85432 Rev. 0 sht's 1 thru 3

H-2-85439 Rev. 0 sht 1 thru 2

H-2-99132 Rev. 0 sht's 1 thru 4

H-2-71840 Rev. 2 sht's 1 thru 2

\subsection{Literature}

AISC, 1989, Manual of Steel Construction - Allowable Stress Design, Ninth Edition, American Institute of Steel Construction, Chicago.

C.G. Salmon, and J.E. Johnson, Steel Structures Design and Behavior, Third Edition, Harper Collins, NewYork.

DOE-RL, 1993, Hanford Site Hoisting and Rigging Manual, DOE-RL-92-36, U.S. Department of Energy, Richland Field Office, Recleaned, Wa.

Machinery's Handbook, Twenty-First Edition.

Omer W. Blodgett, 1976, Design of Weldments. Eighth Printing, Lincoln Arc Welding foundation, Cleveland, Ohio.

Roark, R.J., and W.C. Young, 1989, Roark's Formulas for Stress and Strain, Sixth Edition, McGraw-Hill, New York. 
WHC-SD-WM-DA-158

Revision 0

Page 5 of 2422

7.0 DESIGN CALCULATION

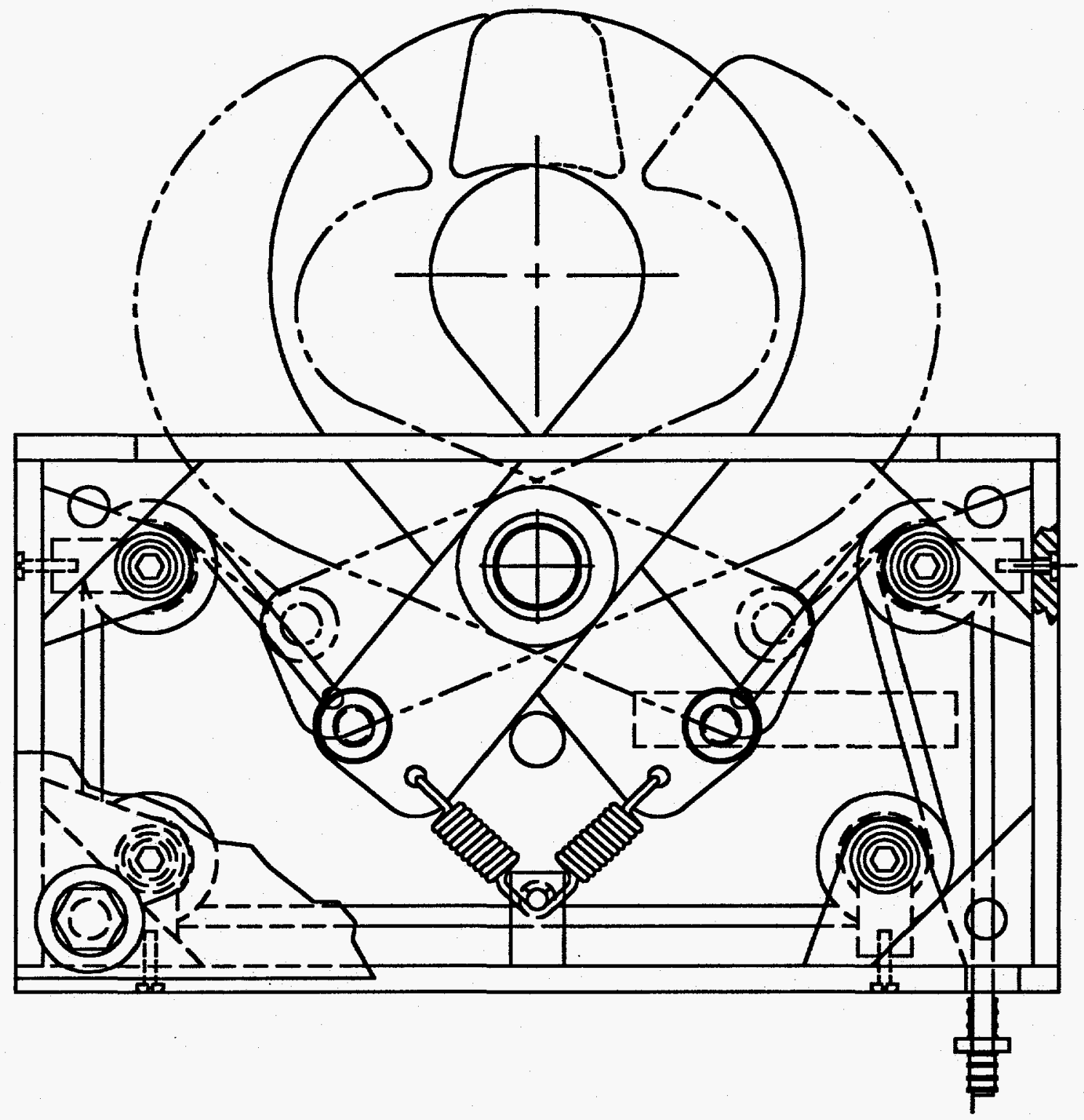

Figure 1

Safety Latch Assembly 


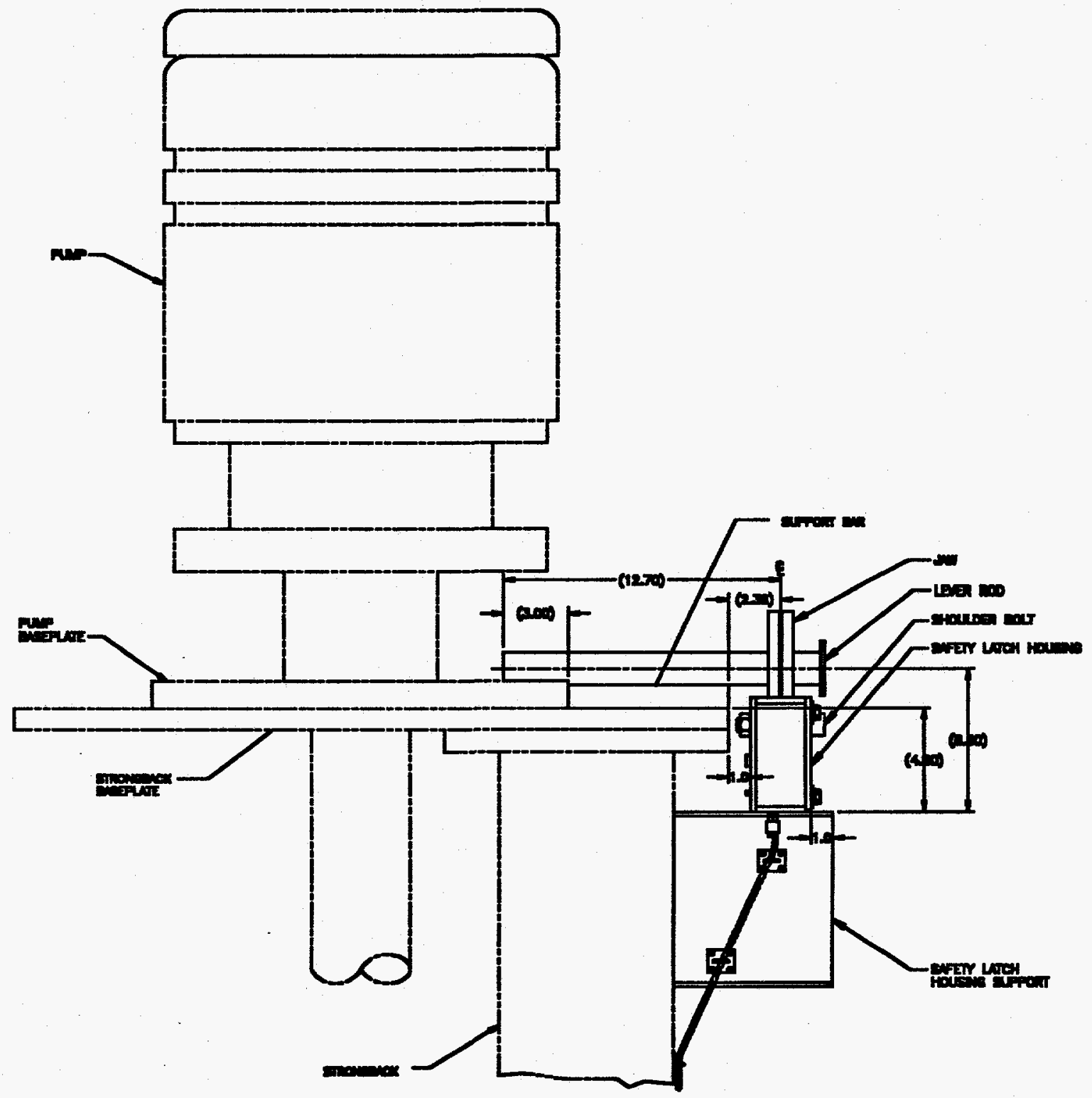

Figure 2

Safety Latch Weldment 


\subsection{List of Symbols}
A area of cross section, in $^{2}$.
ch horizontal distance from c.g. to weld, in.
c. vertical distance from c.g. to weld, in.
f force per inch for welds treated as lines, $\mathrm{lb} / \mathrm{in}$.
$f_{a}$ allowable force per inch for welds treated as lines, $l b / i n$.
$f_{b} \quad$ bending force per inch for welds treated as lines, $l b / i n$.
f shear force, force per inch for welds treated as lines, lb/in.
$f_{v} \quad$ vertical twisting force per inch for welds treated as lines, $l b /$ in.
$I_{c} \quad$ moment of interia, in ${ }^{4}$.
k stress factor for curved beams.
$L_{w}$ length of weld, in.
M bending moment, in-lb.
P Force, lb.
U maximum energy, in-lb
$\mathrm{U}_{\mathrm{u}} \quad$ ultimate energy, in-1b
w weld leg length, in.
$Y_{s} \quad$ yield strength, psi.
$\mathbf{Y}_{\mathbf{u}} \quad$ ultimate stress, psi.
Z section modulus, $\mathrm{in}^{3}$.
$\mathrm{Z}_{\mathrm{w}} \quad$ section modulus for welds treated as lines, $\mathrm{in}^{2}$.
$\sigma_{a} \quad$ allowable stress, psi. 
$\sigma_{\mathrm{B}} \quad$ bearing stress, psi.

$\sigma_{b} \quad$ bending stress, psi.

$\sigma_{\mathrm{w}} \quad$ weld stress, psi.

$\delta$ deflection, in.

$\tau \quad$ shear stress, psi.

$\tau_{t} \quad$ shear stress due to tension, psi.

\subsection{Static Analysis}

[1] Determining the weight of the Strong-Back and Pump.

$8 \times 8 \times 3 / 16$ sq. channel $=19.63 \mathrm{lb} / \mathrm{ft}$

$48^{\prime} \times 19.63=9421 b$

$3^{\prime \prime}$ pipe sch $80 \mathrm{cs}=10.25 \mathrm{lb} / \mathrm{ft}$

35 'x $10.25=3581 \mathrm{~b}$

$8 \times 4 \times 3 / 13$ sq channel $=14.53 \mathrm{lb} / \mathrm{ft}$

$23^{\prime} \times 14.53=3341 \mathrm{~b}$

Total weight of Strong-Back $=\underline{1.634 \mathrm{lb}}$

6" pipe sch 40 pipe, cs $=19.00 \mathrm{lb} / \mathrm{ft}$

43 'x $19=817 \mathrm{~b}$

Pump motor $=5001 \mathrm{~b}$

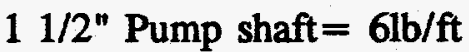

$43^{\prime} \times 6=2581 \mathrm{~b}$

Total weight of pump $=1,5751 \mathrm{~b}$

Total combined weight $=\underline{\mathbf{3 . 2 1 0 l b}}$

[2] Calculate the bearing, shear and bending stress due to a load of $1,634 \mathrm{lbs}$ on one jaw.

Material: $1 / 2^{n}$ plate, AISI $4130, Y s=92,000 \mathrm{psi}$ Allowable stress $92,000 / 3=30,666 \mathrm{psi}$

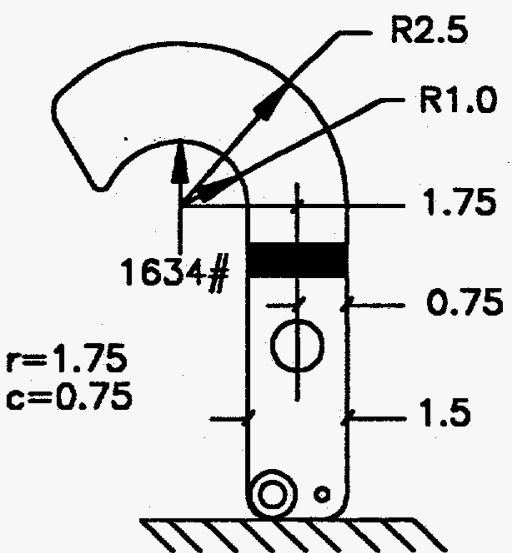


[2a] Calc. the surface area to be in contact with cantilever rod.

$$
\text { surface }=.75 * 2 \pi * \frac{46^{\circ}}{360^{\circ}}=0.60 \mathrm{inch}
$$

[2b] Calc. bearing stress.

$$
\sigma_{B}=\frac{1634}{(0.60 * 0.50)}=5,446 \mathrm{Ib} / \mathrm{inch}^{2}
$$

[2c] Calc. the shear stress in the plate due to the upward load.

$$
\tau=\frac{1634}{0.5 * 1.50}=2,1781 \mathrm{~b} / \text { inch }^{2}
$$

[2d] Calc. the stress due to bending in one jaw.

Assumption: calculate the bending stress for a straight cantilever beam, and multiply it by the stress factor (k) for a curved beam (Reference: Machinery's Handbook, 24 Edition, pg. 242). From pg. 242, for a rectangular cross section:

$\mathrm{r} / \mathrm{c}=1.75 / 0.75=2.3$ therefore

$\mathrm{k}$ inside $=1.52$,

k outside $=0.73$

$\mathrm{M}=1634 * 1.75=2,859 \mathrm{lb}$-inch

$$
I_{c}=\frac{0.5 * 1.5^{3}}{12}=0.141 \text { inch }^{4}
$$

$$
\sigma_{b}=\frac{2859 * 0.75}{0.141}=15,2501 \mathrm{~b} / \mathrm{inch}^{2}
$$

$\sigma_{\mathrm{b} \text { indide }}=15,225 * 1.52=23,181 \mathrm{lb} /$ inch $^{2}$

$\sigma_{\mathrm{b} \text { inside }}<\sigma_{\mathrm{a}} \checkmark$ 
WHC-SD-WM-DA-158

Revision 0

Page 10 of 2422

[3] The following calculations analyze the shear,bending and deflection of the shoulder bolt. The shoulder bolt is assumed to be simply supported, loaded at the center.

Material: 3/4" ASTM A325 type 3, Ys=92,000 psi.

Allowable $=92,000 / 3=30,666$ psi.

[3a] Calc. shear stress due to a load of $1,634 \mathrm{lbs}$, by two clips.

$$
\tau=\frac{1634}{\left(2 \pi * 0.375^{2}\right)}=1,8501 \mathrm{~b} / \text { inch }^{2}
$$

[3b] Calc. the maximum bending stress in the shoulder bolt, assuming a simple supported beam.

$$
\begin{aligned}
M_{\max } & =w l / 4 \\
M_{\max } & =\frac{2.5 * 1634}{4}=1,0211 b-i n c h
\end{aligned}
$$

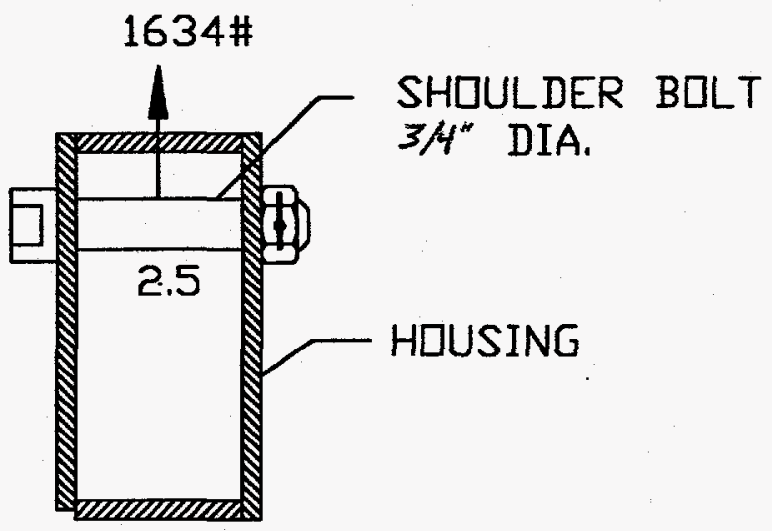

[3c] Calc. the section modulus for the shoulder bolt.

$$
z=\frac{\pi * 0.75^{3}}{32}=0.041 \text { inch }^{3}
$$

[3d] Calc. the bending stress.

$$
\begin{aligned}
& \sigma_{\mathrm{b}}=\mathrm{M}_{\max } / \mathrm{Z} \\
& \sigma_{b}=\frac{1021}{0.041}=24,664 \mathrm{Ib} / \mathrm{inch}^{2} \\
& \sigma_{\mathrm{b}}<\sigma_{\mathrm{a}}
\end{aligned}
$$

[3e] Calc. deflection in the shoulder bolt (information only).

$$
\delta=\frac{1021 * 2.5^{3}}{38 * 30 E 6 * 0.016}=0.001 \mathrm{inch}
$$

[4] The following calculations, analyze the stresses from the applied load, for one side plate of the safety latch housing. 
Material: $1 / 4$ " plate, ASTM A36, Ys $=36,000$ psi Allowable: $36,000 / 3=12,000$ psi

$3 / 8^{\prime \prime}$ bolts, ASTM A307, Ys $=36,000$ psi

Allowable: $36,000 / 3=12,000$ psi

[4a] Calc. bearing stress in the $3 / 4^{\prime \prime}$ diameter hole.

$$
\begin{aligned}
& \sigma_{B}=\frac{1634 / 2}{0.25 * 0.75}=4,3571 \mathrm{~b} / \mathrm{inch}^{2} \\
& \sigma_{B}<\sigma_{\mathrm{a}} \checkmark
\end{aligned}
$$

[4b] Calc. shear stress in the $1 / 4$ plate above the $3 / 4$ " bolt hole.

$$
\begin{aligned}
& \tau=\frac{1634 / 2}{0.25 * 0.875}=3,7341 \mathrm{~b} / \text { inch }^{2} \\
& \tau<\tau_{\mathrm{a}} \checkmark
\end{aligned}
$$
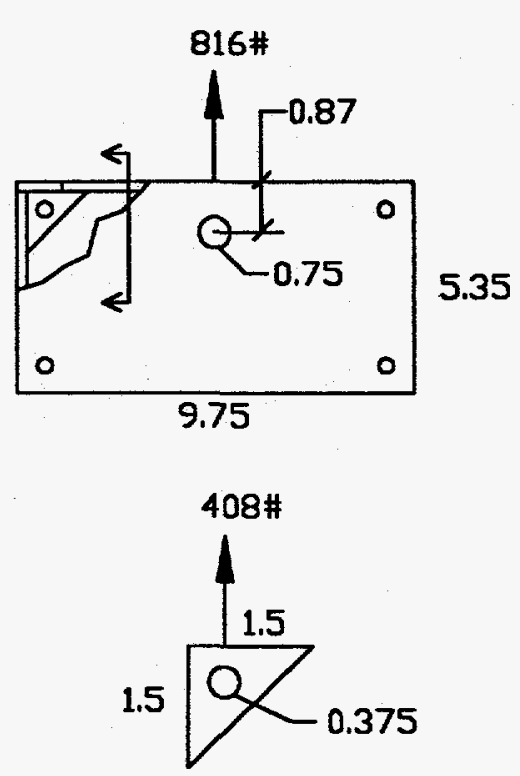

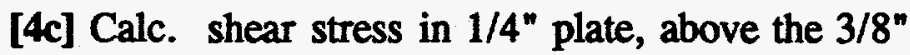
bolt hole.

$$
\begin{aligned}
& \tau=\frac{1634 / 4}{0.25 * 0.50}=3,2681 \mathrm{~b} / \mathrm{inch}^{2} \\
& \tau<\tau_{\mathrm{a}}
\end{aligned}
$$

[4d] Calc. shear stress in $3 / 8$ in bolt.

$$
\begin{aligned}
& \tau=\frac{408}{\pi * 0.187^{2}}=3,6951 \mathrm{~b} / \text { inch }^{2} \\
& \tau<\tau_{\mathrm{a}} \checkmark
\end{aligned}
$$

[4e] Calc. bearing stress in one $3 / 8^{\prime \prime}$ diameter hole.

$$
\sigma_{B}=\frac{408}{0.375 * 0.25}=4,3521 \mathrm{~b} / \text { inch }^{2} \quad \sigma_{B}<\sigma_{\mathrm{B}} \checkmark
$$


[4f] Calc. tension in one angle support.

$\tau_{\mathrm{t}}=\mathrm{P} / \mathrm{A}_{\mathrm{a}}$

$A_{n}=t\left(\omega_{g}-N \omega_{h}\right)$

$\mathrm{t}=$ plate thickness.

$\omega_{\mathrm{g}}=$ gross width of plate.

$\omega_{\mathrm{h}}=$ diameter of hole

$\mathbf{N}=$ number of holes in the section being considered

$$
\begin{aligned}
& \tau_{t}=\frac{408}{0.25[0.75-(0.375+0.062)]}=5,222 \mathrm{Ib} / \text { inch }^{2} \\
& \tau_{t}<\tau_{2} \checkmark
\end{aligned}
$$

[4g] Calc. the transverse force induced in the fillet welds of the housing.

$$
f=\frac{P}{L}
$$

$$
f=1634 /(2 * 9.75+2 * 2.25)=681 b / \text { inct }
$$

[4h] Calc. the required weld size using a 6016 welding rod.

The allowable shear stress for a 6016 rod is 18,000 psi.

$$
\begin{aligned}
& w=\frac{P}{\left(0.707 * \sigma_{\text {aw }}\right)} \\
& w=\frac{1634}{(0.707 * 18000)} \\
& w=0.128 \text { inch }
\end{aligned}
$$

design weld size $3 / 16(0.187)>0.128 \checkmark$

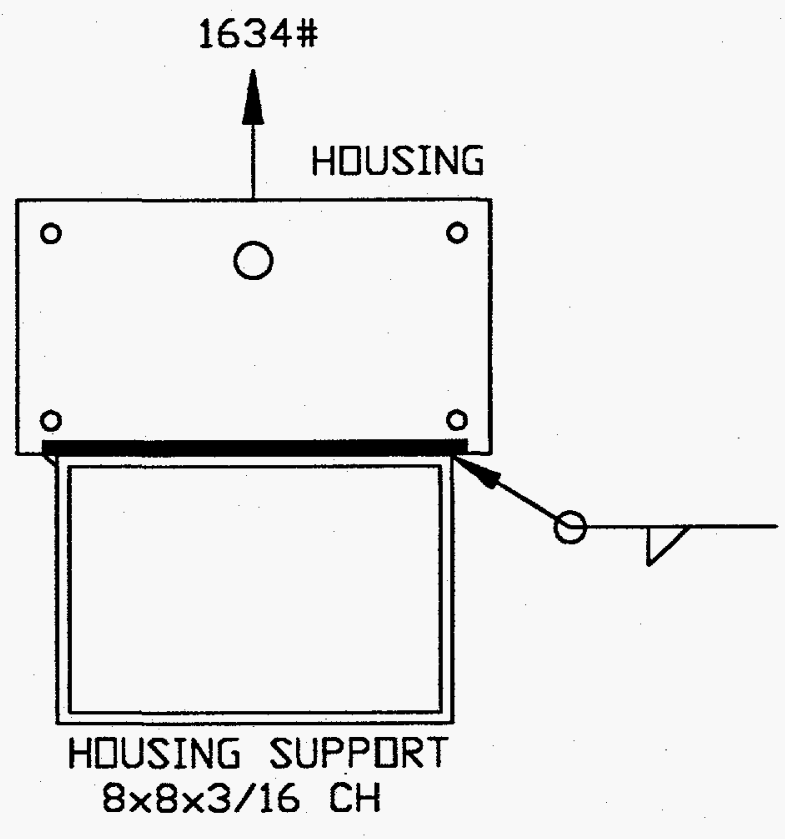

[4i] Calc stress induced in the weld. 


$$
\sigma_{w}=\frac{68}{0.187 * 0.707}
$$

$$
\sigma_{\mathrm{w}}=514 \mathrm{psi}
$$

[5] Calculate the bending in the $11 / 2^{n}$ diameter lever rod, welded on the pump base plate.

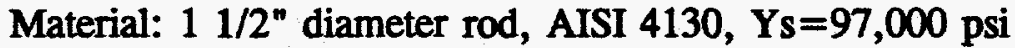

Allowable $=97,000 / 3=32,333$ psi

Assumption: The moment will be taken $2.375^{\mathrm{m}}$ in from the right end of the lever rod, and not at the welded end, since the support bar relieves the stresses at the weld.

Calc. the maximum moment

$$
M_{\max }=1634 * 2.375=3,8801 b-i n c h
$$

Calc. the section modulus.

$$
z=\frac{\pi * 1.50^{3}}{32}=0.331 \mathrm{inch}^{3}
$$

Calc. the bending stress.

$$
\sigma_{b}=\frac{3880}{0.331}=11,7241 b / \text { inch }^{2}
$$

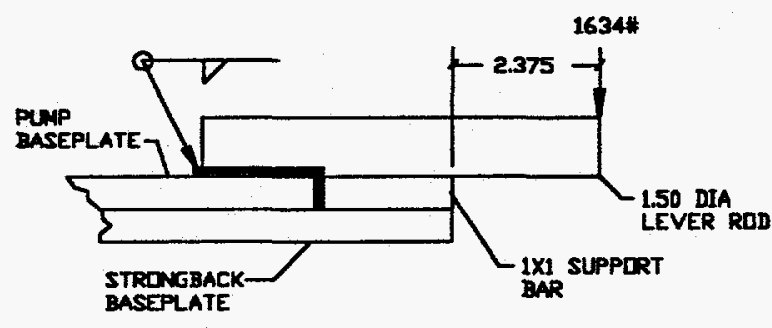

$\sigma_{\mathrm{b}}<\sigma_{\mathrm{a}} \checkmark$

[6] Calculate the section modulus of the weld, for the cantilever rod. Reference pg. 276 of Salmon and Johnson, Steel Structures Design and Behavior, for the section modulus. The weld is assumed to be a straight line.

$$
z_{\mathrm{w}}=1 * 3+\frac{3^{2}}{3}=6.0 \mathrm{inch}^{2}
$$

[6a] Calc. force in the weld due to bending.

$$
f_{b}=\frac{4902}{6.0}=8171 \mathrm{~b} / \mathrm{inch}
$$


[6b] Calc. the required weld size using a 8016-B2.

The allowable weld shear is the allowable of the base metal 12,000 psi.

$$
w=\frac{817}{0.707 * 12000}=0.096 \text { inch }
$$

The design weld is $5 / 16(0.313)>0.096 \checkmark$

[6d] Calc. the induced stress in the weld.

$$
\sigma_{w}=\frac{817}{0.313 * 0.707}
$$

$\sigma_{\mathrm{w}}=3,691 \mathrm{psi}$

[7] Calculate the required spring constant, used for opening and closing the jaws.

$$
\begin{array}{ll}
\text { Deflection } \delta & =1.60 \text { (open jaw) } \\
\text { O.D. of spring } & =0.187 \\
\text { Center line } D & =0.375-0.0418=0.327 \\
\text { Gage d }(19 \mathrm{Ga}) & =0.0418 \\
\text { Modulus } \mathrm{G} & =11.5 \mathrm{E} 6 \mathrm{psi} \\
\text { Number of coils N } & =10 \\
\text { Spring Const. } \mathrm{K} & =?
\end{array}
$$

$$
P=\frac{\delta G d^{4}}{8 D^{3} N}=\frac{1.6 * 11.5 E 6 * 0.0418^{4}}{8 * 0.327^{3} * 10}
$$

$\mathbf{P}=20 \mathrm{lb}$

For two springs in parallel

$P_{\mathrm{T}}=2 * 20=40 \mathrm{lbs}$

$\mathrm{K}=\mathrm{P} / \delta=20 / 1.6=12.50 \mathrm{lbs} / \mathrm{in}$

[8] The following calculations analyzes the induced stresses in the safety latch housing support, which will be welded to the back side of the strong-back.

Material $8 \times 8 \times 3 / 16 \times 5^{\prime \prime} \mathrm{lg}$. steel tube ASTM A36, Ys $=36,000$ Section Modulus $Z=14.6$ in $^{3}$ Reference pg I-95 of the AISC. Allowable $36,000 / 3=12,000 \mathrm{psi}$ 
Calc. the maximum bending.

$M_{\max }=1634 * 7$

$M_{\max }=11,438$ lb-inch

Calc. the bending stress

$$
\sigma_{b}=\frac{11438}{14.6}=783 \mathrm{lbs} / \text { inch }^{2}
$$

$\sigma_{\mathrm{b}}<\sigma_{\mathbf{a}} \checkmark$

[8a] Calc. the section modulus for the

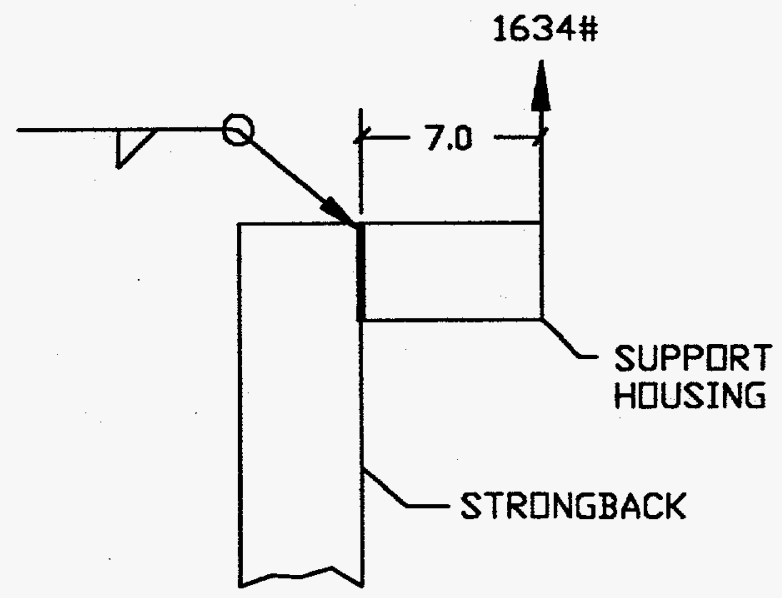
weld.

Reference pg. 276 of Salmon and Johnson, Steel Structures Design and Behavior, for the section modulus.

$$
z_{w}=8 * 8+\frac{8^{2}}{3}=85 \cdot 3 \text { inch }^{2}
$$

Calc. force due to bending in the weld.

$$
f_{b}=\frac{11438}{85.3}=1341 \mathrm{~b} / \mathrm{inch}
$$

Calc. the required weld size using a 6016 rod.

the allowable shear stress is 18,000 psi

$$
w=\frac{134}{0.707 * 18000}=0.011 \mathrm{inch}
$$

Design weld is $3 / 16(0.188)>0.011 \checkmark$

[8b] Calc. the induced stress in the weld.

$$
\begin{aligned}
& \sigma_{w}=\frac{134}{0.188+0.707} \\
& \sigma_{w}=1,008 \mathrm{psi}
\end{aligned}
$$




\subsection{Dynamic Analysis}

[1] The conditions for analyzing the dynamic loading on the safety latch and the cantilever rod are:

1. The strong-back must be lifted off the trailer or shop floor.

2. The friction clamps must fail.

If both conditions occur, the strong-back safety latch (which is attached to the strong-back) would drop onto the cantilever rod (which is attach to the pump) causing shock loading.

The following calculation determines the energy absorbed first in the elastic then in the plastic range of each component (if required).

[1a] Calculate Kinetic energy if the strong-back were to fall 0.25 inches.

$$
\begin{aligned}
& V=\sqrt{2 * 387 * 0.25}=14 \mathrm{inch} / \mathrm{s} \\
& K E=\frac{1634 * 14^{2}}{2 * 387}=414 \mathrm{inch}-1 \mathrm{~b}
\end{aligned}
$$

[1b] Calculate maximum energy which can be absorb in one jaw of the safety latch without deforming in the elastic range, using AISI 4130 (reference the Design of Weldments, page 3.1-5 Table 3) is.

$$
U=\frac{Y_{s}^{2} * I * L}{6 * E * C^{2}}
$$

Yield stress $\left(Y_{2}\right)=97,000$ psi

Distance (L) from the center line of the jaw to the load $=1.75$ in.

$\mathrm{I}=.141 \mathrm{in}^{4}$

$\mathrm{E}=30 \mathrm{E} 6 \mathrm{psi}$

$\mathrm{c}=0.75$ in

$$
U=\frac{97000^{2} * .141 * 1.75}{6 * 30 E 6 * 0.75^{2}}=23 \text { inch }-1 b
$$

23 in-lb $<\mathrm{KE}$, which exceeds the elastic region. Therefore, calculate the ultimate energy which can be absorbed: 


$$
U_{u}=\frac{Y_{B}+Y_{u}}{2} * \epsilon_{u} * A * L
$$

From the Stress - Strain curves (reference ASM, Atlas of Stress Strain Curves, pg 222). Elongation $\epsilon_{\mathrm{u}}=0.11 \mathrm{in} / \mathrm{in}$ at a strain rate of $60 \mathrm{in} / \mathrm{in} / \mathrm{min}$.

Cross section area $(A)$ of the jaw $=(0.5 * 1.5)=0.75$ in $^{2}$

Distance $(\mathrm{L})$ from the center line of the jaw to the load $=1.75 \mathrm{in}$.

Ultimate stress $\left(Y_{u}\right)=115,000$ psi.

$$
U_{u}=\frac{97000+115000}{2} * 0.11 * 1.75 * 0.75=15,303 \text { inch }-16
$$

\section{5,303 in-lb > KE $\checkmark$}

[2] Calculate the maximum energy which can be absorbed in the shoulder bolt. Utilizing the same two formulas which were used for the Jaw.

$I=0.016$ in $^{4}$

$L=1.25$ in

$\mathrm{E}=30 \mathrm{E} 6 \mathrm{psi}$

$c=0.375$ in

$\mathrm{U}=6.7 \mathrm{in}-\mathrm{lb}<\mathrm{KE}$, exceeds the elastic range.

[2a] Calculate the ultimate energy which can be absorbed.

Elongation $\epsilon_{\mathrm{u}}=0.11 \mathrm{in} / \mathrm{in}$.

Cross section area (A) of the jaw $=\left(\pi^{*} .375^{2}\right)=0.44$ in $^{2}$

Distance $(\mathrm{L})=1.25$ in.

Ultimate stress $\left(Y_{u}\right)=115,000$ psi.

Yield stress $\left(Y_{2}\right)=92,000$ psi.

$$
U_{u}=\frac{92000+115000}{2} * 0.11 * 0.44 * 1.25=6,261 \text { inch }-1 b
$$

$\mathrm{U}_{\mathrm{u}}=6,261 \mathrm{in}-\mathrm{lb}>\mathrm{KE} \checkmark$

[3] Calculate the maximum energy which can be absorbed in the cantilever rod utilizing the same two formulas.

$\mathrm{I}=0.25 \mathrm{in}^{4}$

$\mathrm{L}=3$ in 
$E=30 E 6$ psi

$c=0.75$ in

Yield stress $\left(Y_{\sharp}\right)=97,000$ psi

$\mathrm{U}=70.0$ in- $-\mathrm{b}<\mathrm{KE}$

[3b] Calculate the ultimate energy which can be absorbed.

Elongation $\epsilon_{v}=0.11$ in/in.

Cross section area $(A)=\left(\pi^{*} 0.75^{2}\right)=1.76 \mathrm{in}^{2}$

Distance $(\mathrm{L})=3.0$ in.

Ultimate stress $\left(Y_{\mho}\right)=115,000$ psi.

$\mathrm{U}_{\mathrm{u}}=61,546 \mathrm{in}-\mathrm{lb}>\mathrm{KE} \checkmark$

[4] Calculate the maximum energy which can be absorbed in one plate of the housing.

$\mathrm{I}=122 \mathrm{in}^{4}$

$\mathrm{L}=4.875$ in

$\mathrm{E}=30 \mathrm{E} 6 \mathrm{psi}$

$\mathrm{c}=2.66$ in

Yield stress $\left(Y_{2}\right)=36,000 \mathrm{psi}$

$\mathrm{U}=605 \mathrm{in}-\mathrm{b} \mathrm{b}>\mathrm{KE} \checkmark$

[5] Calculate the maximum energy which can be absorbed in the housing support.

$\mathrm{I}=59.6 \mathrm{in}^{4}$

$\mathrm{L}=7.0$ in

$\mathrm{E}=30 \mathrm{E} 6 \mathrm{psi}$

$c=4$ in

Yield stress $\left(Y_{2}\right)=36,000$ psi

$\mathrm{U}=187.7 \mathrm{in}-\mathrm{lb}<\mathrm{KE}$

[5b] Calculate the ultimate energy which can be absorbed.

Elongation $\epsilon_{v}=0.35 \mathrm{in} / \mathrm{in}$.

Cross section area $(A)=5.86 \mathrm{in}^{2}$

Distance $(L)=7.0$ in.

Ultimate stress $\left(Y_{w}\right)=60,000$ psi.

$\mathrm{U}_{\mathrm{u}}=689,000 \mathrm{in}-\mathrm{lb}>\mathrm{KE} \checkmark$ 
If shock loading were to occur, possible deformation could result, but failure in the material would not since the ultimate energy which could be absorbed is greater the kinetic energy (reference ASM, Atlas of Stress Strain Curves).

[6] Calculate the required weld size (w) due to shock loading in each of the components.

Calc. safety factor from the applied load.

$\mathrm{sf}=1634 * 3=4902 \mathrm{lb}$

Calc. the moment for the cantilever rod.

$M=4902 * 3=14,706$ in $-1 b$

Calc. the bending stress due to impact.

Section modulus for the weld $=6 \mathrm{inch}^{2}$. From section 7.1 step [6].

$$
\sigma_{b}=\frac{14707}{6}=2,4511 b / \text { inch }
$$

Calc. the shear stress due to shock loading.

Length of weld $=8$ inch.

$$
\tau=\frac{4902}{8}=6131 \mathrm{~b} / \mathrm{inch}
$$

Calc. the total stress.

$$
\sigma_{b}+\tau=30641 b / \text { inch }
$$

Calc. the required weld size.

welding rod 8016-B2

The allowable weld shear stress for the base metal is 14,400 psi

$$
w=\frac{3064}{0.707 * 14400}=0.30 \mathrm{inch}
$$

Design weld size $5 / 16^{\prime \prime}(0.312)>0.30 \checkmark$

[7] Calculate the required weld size for the safety latch housing.

Calc. transverse stress on weld.

Length of weld 22 inch. 


$$
\tau=\frac{14706}{22}=6681 \mathrm{~b} / \mathrm{inch}
$$

Calc. required weld size.

welding rod 8016

The allowable shear stress for a 6016 rod is 18,000 psi.

$$
w=\frac{668}{0.707 * 18000}=0.05 \mathrm{inch}
$$

Design weld size $3 / 16^{\prime \prime}(0.187)>0.05 \checkmark$

[8] Calculate the required weld in the safety latch housing support.

Calc. the moment.

$\mathrm{M}=4902 * 7=34,321$ inch-lb

Calc. the bending stress due to impact.

Section modulus for the weld $=85.3 \mathrm{inch}^{2}$. From section 7.1 step [8]

$$
\sigma_{b}=\frac{34321}{85.3}=4021 \mathrm{~b} / \mathrm{inch}
$$

Calc. the shear stress due to impact.

Length of weld $=32$ inch.

$$
\tau=\frac{34321}{32}=1,0721 \mathrm{~b} / \text { inch }
$$

Calc. the total stress due to impact.

$$
\sigma_{b}+\tau=1,474 \mathrm{lb} / \text { inch }
$$

Calc. required weld size.

welding rod 6016

The allowable weld shear stress for a $6016 \mathrm{rod}=18,000$ psi.

$$
w=\frac{1474}{0.707 * 18000}=0.116 \mathrm{inch}
$$

Design weld size $3 / 16$ inch.

$3 / 16(0.187)>0.116$ \& 
WHC-SD-WM-DA-158

Revision 0

Page 21 of $2 / 22$

\section{APPENDIX A}

TABULATED STRESS

\begin{tabular}{|l|l|l|l|}
\hline $\begin{array}{c}\text { Stress } \\
\text { psi }\end{array}$ & $\begin{array}{c}\text { *Jaw, } \\
\text { AISI 4130 } \\
\mathrm{Y}_{\mathrm{S}}=92,000 \mathrm{psi}\end{array}$ & $\begin{array}{c}\text { Shoulder Bolt, } \\
\text { ASTM A325 } \\
\mathrm{Y}_{\mathrm{s}}=92,000 \mathrm{psi}\end{array}$ & $\begin{array}{c}\text { Side Plate } \\
\text { ASTM A36 } \\
\mathrm{Y}_{\mathrm{S}}=36,000 \mathrm{psi}\end{array}$ \\
\hline$\sigma_{\mathrm{b}}$ & 23,181 & 24,664 & - \\
\hline$\tau$ & 2,178 & 1,021 & 3,268 \\
\hline$\sigma_{\mathrm{w}}$ & & & 513 \\
\hline & Lever Rod & & Housing Support \\
\hline$\sigma_{\mathrm{b}}$ & 14,809 & & 783 \\
\hline$\tau$ & & & \\
\hline$\sigma_{\mathrm{w}}$ & 3,691 & & 385 \\
\hline
\end{tabular}

* The stress shown represents the stress in one jaw. The actual safety latch consist of two jaw, therefore the actual stress is one half the stress shown. 
WHC-SD-WM-DA-158

Revision 0

Page 22 of 2422

APPENDIX B

WELDING PROCEDURE 